\title{
Midterm performance of a novel restorative pulmonary valved conduit: preclinical results
}

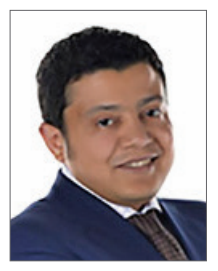

Osama I. Soliman ${ }^{1,2 *}$, MD, PhD; Yosuke Miyazaki ${ }^{1}, \mathrm{MD}, \mathrm{PhD}$; Mohammad Abdelghani ${ }^{3}$, MD; Marieke Brugmans ${ }^{4}, \mathrm{PhD}$; Maarten Witsenburg ${ }^{5}, \mathrm{MD}, \mathrm{PhD}$; Yoshinobu Onuma ${ }^{1,2}, \mathrm{MD}, \mathrm{PhD}$; Martijn $\mathrm{Cox}^{4}$, PhD; Patrick W. Serruys ${ }^{6}, \mathrm{MD}, \mathrm{PhD}$

1. Department of Cardiology, Thoraxcenter, Erasmus Medical Center Rotterdam, Rotterdam, the Netherlands; 2. Cardialysis, Rotterdam, the Netherlands; 3. Department of Cardiology, Academic Medical Center Amsterdam, Amsterdam, the Netherlands; 4. Xeltis BV, Eindhoven, the Netherlands; 5. Department of Paediatric Cardiology, Thoraxcenter, Erasmus Medical Center Rotterdam, Rotterdam, the Netherlands; 6. International Centre for Circulatory Health, Imperial College London, London, United Kingdom

GUEST EDITOR: Alec Vahanian, MD, PhD; Department of Cardiology, Hôpital Bichat, Paris, and University Paris VII, Paris, France

\section{KEYWORDS}

- bioresorbable

scaffolds

- degenerative valve

- endogenous tissue

restoration

- pulmonary stenosis

- transthoracic

echocardiogram

\section{Abstract}

Aims: The Xeltis bioabsorbable pulmonary valved conduit (XPV), designed to guide functional restoration of patients' own tissue, is potentially more durable than current pulmonary bioprosthetic valves/valved conduits. The aim of this study was to assess the haemodynamic performance of the novel XPV implanted in an ovine model.

Methods and results: The XPV was surgically implanted in adult sheep under general anaesthesia and cardiopulmonary bypass (XPV group, $\mathrm{n}=20$ ). Sheep that received a Hancock bioprosthetic pulmonary valved conduit served as a control group (HPV group, $n=3$ ). Transthoracic echocardiograms from VARC-2 recommended time points at 3, 6, 9, 12, 18 and 24 months (XPV group) and at 3 and 6 months (HPV group) after the procedure were analysed in an independent core laboratory. The primary endpoint was favourable valved conduit performance, defined as peak systolic pressure gradient $<40 \mathrm{mmHg}$, no severe pulmonary regurgitation (PR), and a maximum conduit patency index of $-20 \%$. In the latter, negative values denote luminal narrowing and vice versa. The valvular peak systolic pressure gradient $(\mathrm{mmHg})$

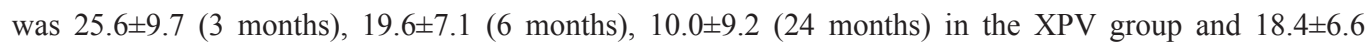
(3 months), 17.7 \pm 4.6 (6 months) in the HPV group. The patency index (\%) of the conduit at the valvular level was $+30.3 \pm 13.6$ ( 6 months) and $+64.1 \pm 1.4$ ( 24 months) in the XPV group and $+2.0 \pm 15.9$ ( 6 months) in the HPV group. PR was trace or mild at all visits, except in one animal with persistent moderate PR in the XPV group, up to 24 months.

Conclusions: The XPV showed a favourable and durable haemodynamic performance (up to two years after implantation), without conduit narrowing/obstruction or severe regurgitation.

\footnotetext{
*Corresponding author: Thoraxcenter, Erasmus Medical Center Rotterdam, 's-Gravendijkwal 230, 3015 CE Rotterdam, the Netherlands.E-mail: o.soliman@erasmusmc.nl
} 


\section{Abbreviations}

$\begin{array}{ll}\text { ETR } & \text { Endogenous Tissue Restoration } \\ \text { HPV } & \text { Hancock pulmonary valved bioprosthesis } \\ \text { PA } & \text { pulmonary artery } \\ \text { PR } & \text { pulmonary regurgitation } \\ \text { RV } & \text { right ventricle } \\ \text { RVOT } & \text { right ventricular outflow tract } \\ \text { XPV } & \text { Xeltis pulmonary valved conduit }\end{array}$

\section{Introduction}

Congenital defects involving the right ventricular outflow tract (RVOT) and the pulmonary artery (PA), such as tetralogy of Fallot, pulmonary atresia, or transposition of the great arteries with pulmonary stenosis, represent about $20-40 \%$ of patients with congenital heart disease who survive until adulthood ${ }^{1,2}$. Reconstruction of the RVOT is part of the surgical repair of these conditions, and inevitably portends recurrent RVOT dysfunction requiring the implantation of a right ventricle (RV)-to-PA conduit or a prosthetic pulmonary valve. Unfortunately, the lifespan of these conduits is much shorter than the lifespan of the recipient patients because they degenerate, resulting in pulmonary regurgitation (PR), with resultant progressive RV dilation and failure ${ }^{3-6}$. In addition, these conduits do not allow for the natural growth of the child. In order to overcome these limitations, the development of more biocompatible conduits that have the potential to grow has been a challenging quest in recent years. The approaches to engineering a biocompatible pulmonary valve with growth potential typically involve the seeding of cells (endothelial cells, stem cells, amniotic fluid-derived cells, or autologous progenitor cells) to populate various scaffolds composed of biodegradable polymers, autologous tissue, or allograft or xenograft matrixes ${ }^{7-13}$. More recently, a new technology was developed based on a biodegradable polymer matrix designed to enable Endogenous Tissue Restoration (ETR) without the use of stem cells or animal-derived products ${ }^{14}$. The novel polymeric valved conduit allows the patient's own cells to infiltrate and trigger a cascade of physiological events leading to gradual replacement of prosthetic material by native tissue. In this study, we sought to investigate the midterm performance of a novel biodegradable polymeric pulmonary valved conduit (XPV) in a sheep model.

Editorial, see page 1379

\section{Methods \\ STUDY DESCRIPTION}

The study included 23 adult Swifter sheep (age: two to four years, weight: $60-90 \mathrm{~kg}$ ). The pulmonary valved conduit (Xeltis BV, Eindhoven, the Netherlands) was implanted in 20 sheep (XPV group) while the $22 \mathrm{~mm}$ Hancock ${ }^{\circledR}$ bioprosthetic valved conduit (Medtronic, Minneapolis, MN, USA), which consists of a porcine aortic valve sutured into the centre of a woven fabric conduit was implanted in three control sheep (HPV group). Two animals died early after implantation of the XPV because of arrhythmia and extensive clamping during the procedure. A third animal was sacrificed after five months due to infective endocarditis. Nine animals have no data available. Nine animals eventually constituted the XPV group available for follow-up. The study flow chart is shown in Figure 1.

The study protocol adhered to the Directive 2010/63/EU of the European Parliament and of the Council of 22 September 2010 on the protection of animals used for scientific purposes and the Guide for the Care and Use of Laboratory Animals and was reviewed and approved by the Test Facility's Ethical Committee for compliance with regulations prior to study initiation (EC approval no. EC MxCl 2014 - 027).

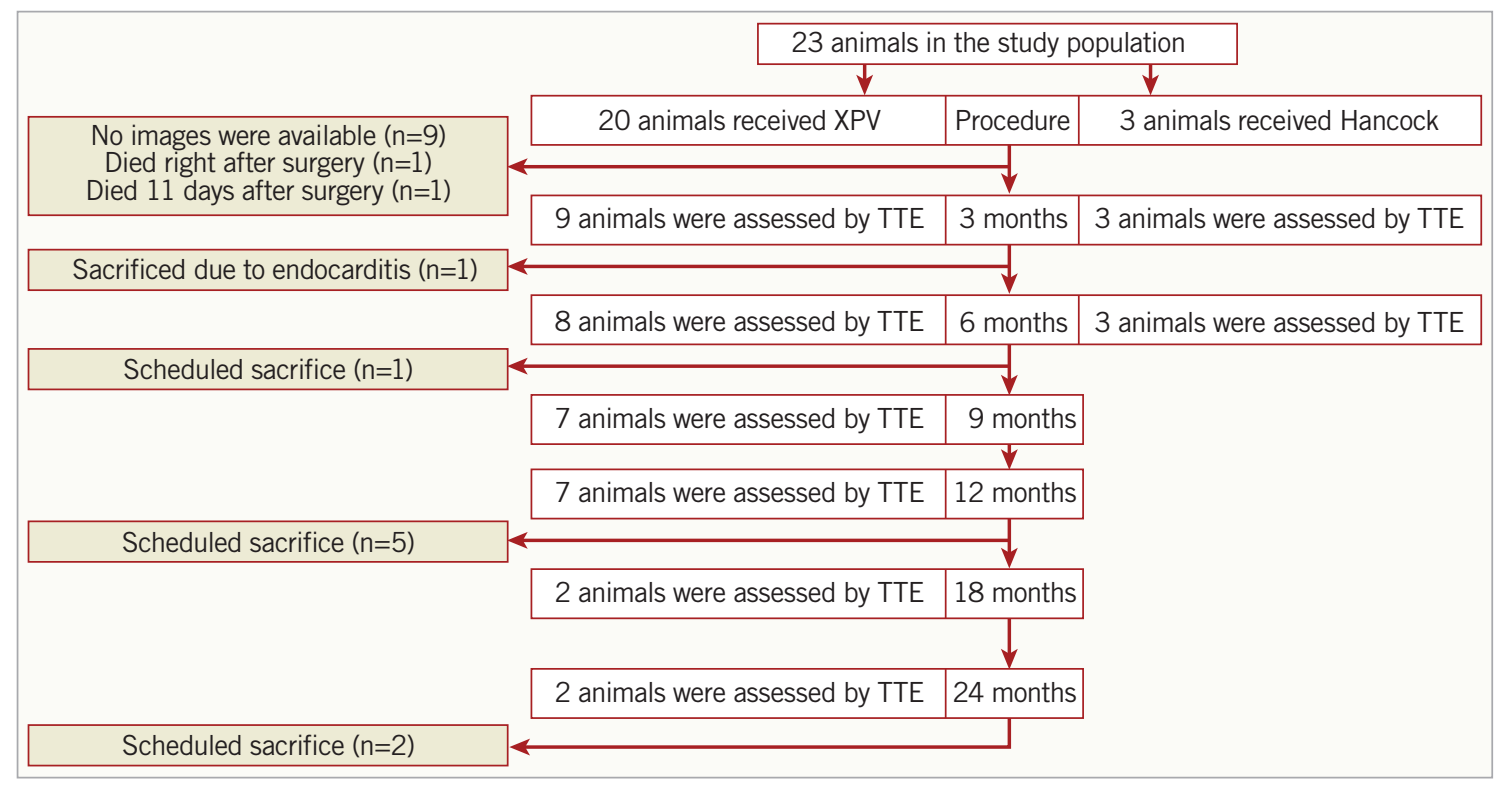

Figure 1. Flow chart of the study and the key echocardiographic assessment time points. TTE: transthoracic echocardiography 


\section{THE BIODEGRADABLE PULMONARY VALVED CONDUIT DESCRIPTION}

The XPV is a flexible, highly porous conduit with three leaflets, fabricated by electrospinning from a novel supramolecular elastomer. The XPV has a length of $5 \mathrm{~cm}$ and an inner diameter of $21 \mathrm{~mm}$. The concept of XPV is based on ETR, in which gradual restoration of the absorbable leaflet and conduit wall by the patient's own cells takes place. The leaflet and conduit are infiltrated by inflammatory cells, which release growth factors and promote smooth muscle cell infiltration and matrix (proteoglycans and collagen with focal elastic tissue) production, while the same inflammatory cells also ensure the absorption of the polymeric implants.

\section{SURGICAL TECHNIQUE AND POSTOPERATIVE MANAGEMENT}

The conduits (XPV $21 \mathrm{~mm}$ or HPV $22 \mathrm{~mm}$ ) were surgically implanted under general anaesthesia and normothermic cardiopulmonary bypass on the beating heart. The heart was exposed by a left anterolateral thoracotomy through the third intercostal space. After transection of the native pulmonary artery, the graft was implanted as an interposition pulmonary artery vascular graft $0.5-1.0 \mathrm{~cm}$ above the native pulmonary valve, the leaflets of which had been surgically removed. The antithrombotic regimen consisted of enoxaparin (Clexane ${ }^{\circledR}$; Sanofi Aventis, Diegem, Belgium) $20 \mathrm{mg}$ twice daily and aspirin (Aspegic ${ }^{\mathbb{R}}$; Sanofi Aventis) subcutaneous injection $250 \mathrm{mg}$ for five days.

\section{ECHOCARDIOGRAPHIC ACQUISITION}

Echocardiographic acquisition was performed using a Vivid-I (GE Healthcare, Chicago, IL, USA) ultrasound machine in accordance with a pre-specified protocol in the Animal Test Facility (Medanex, Diest, Belgium). Transthoracic echocardiography (TTE) was performed on conscious animals at the following time points: preoperative, one week after the procedure, every four weeks thereafter up to two years, and one week before animal sacrifice. Standard echocardiographic views were used to obtain two-dimensional (2D), spectral Doppler, and colour Doppler interrogation of the pulmonary valve, RVOT, and the main PA. For the assessment of the pulmonary valved conduit performance, echocardiographic acquisition included the following views: 2D images of the entire conduit as well as pulsed wave (PW) Doppler, continuous wave (CW) Doppler, and colour Doppler at the subvalvular, valvular, and distal conduit regions.

\section{CORE LABORATORY ECHOCARDIOGRAPHIC ANALYSIS}

As recommended by the Valve Academic Research Consortium (VARC)-2 guidelines, we chose mandated timelines for echocardiographic analysis ${ }^{15}$. Transthoracic echocardiograms at 3, 6, 9, 12, 18 and 24 months (XPV group) after implantation were analysed for XPV primary and secondary performance endpoints. Comparison between the XPV and HPV groups was performed at 3 and 6 months after the procedure.

All transthoracic echocardiograms were analysed in an independent core laboratory (Cardialysis, Rotterdam, the Netherlands) using the Image Arena version 4.6.3 workstation (TOMTEC, Munich, Germany). Measurements of Doppler velocities and 2D dimensions were performed in accordance with published guidelines ${ }^{16-19}$. Figure 2 displays the locations at which the echocardiographic measurements of the conduit diameters and performance indices were performed.

\section{CONDUIT FUNCTION}

Haemodynamic assessments included peak velocity $(\mathrm{m} / \mathrm{sec})$ and mean and peak pressure gradients $(\mathrm{mmHg})$ at the subvalvular and valvular levels of the conduit. Mean and peak pressure gradients were derived from PW or CW Doppler by manually tracing the spectral systolic velocity curves.

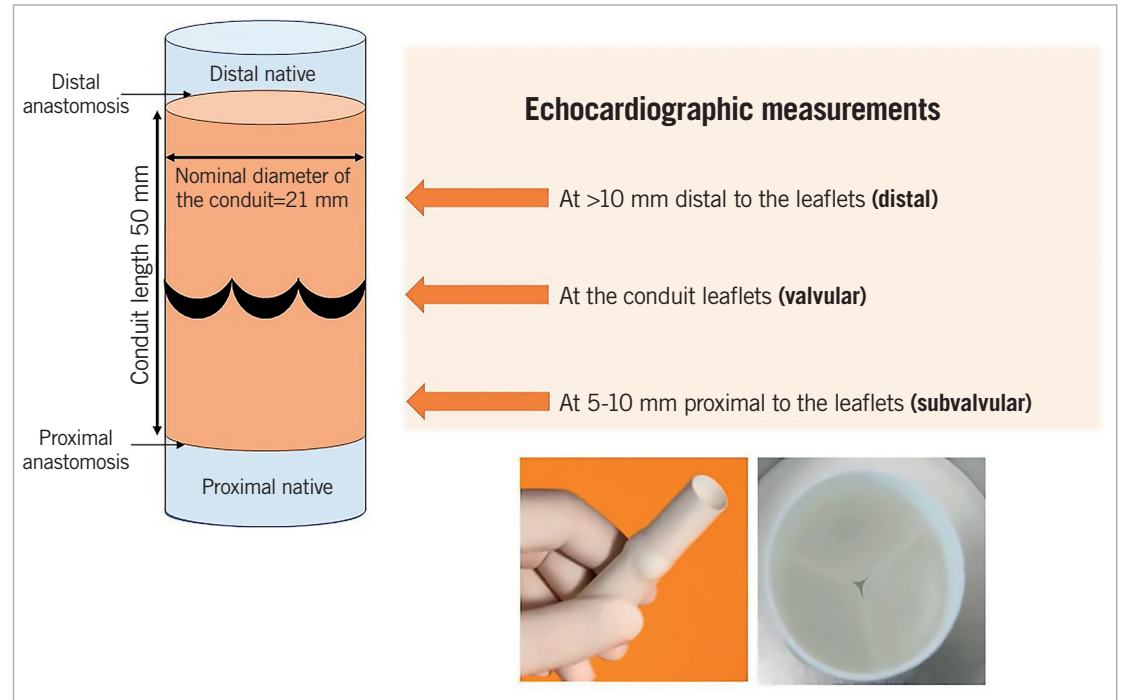

Figure 2. Diagram displaying the locations of echocardiographic measurements of the pulmonary valved conduit morphology and function. 
Severity of pulmonary valve regurgitation (PR) was graded on a five-grade scale as none, trace, mild, moderate, or severe based on jet width criteria (Table 1) and/or colour Doppler flow reversal criteria (Table 2) ${ }^{20}$. Clinically relevant PR was defined as at least mild PR.

Table 1. Jet width criteria of pulmonary regurgitation severity.

\begin{tabular}{|l|l|}
\hline \multicolumn{1}{|c|}{ Grade } & \multicolumn{1}{c|}{ Description } \\
\hline None & No diastolic colour flow jet \\
\hline Trace & Pinhole colour flow jet on ventricular side of the leaflets \\
\hline Mild & Jet width $<20 \%$ of the valve/conduit width* \\
\hline Moderate & Jet width $20 \%$ to $40 \%$ of the valve/conduit width \\
\hline Severe & Jet width $>40 \%$ of the valve/conduit width \\
\hline *As measured at the valvular (leaflet) level.
\end{tabular}

Table 2. Flow reversal criteria of pulmonary regurgitation severity.

\begin{tabular}{|l|l|}
\hline \multicolumn{1}{|c|}{ Grade } & \multicolumn{1}{c|}{ Description } \\
\hline None & $\begin{array}{l}\text { No diastolic colour flow reversal at level of the valve } \\
\text { leaflets }\end{array}$ \\
\hline Trace & $\begin{array}{l}\text { Diastolic colour flow reversal beginning at the valve } \\
\text { leaflets }\end{array}$ \\
\hline Mild & $\begin{array}{l}\text { Diastolic colour flow reversal extending above the valve } \\
\text { leaflets but confined to proximal half of main PA }\end{array}$ \\
\hline Moderate & $\begin{array}{l}\text { Diastolic colour flow reversal extending into distal main } \\
\text { PA }\end{array}$ \\
\hline Severe & Diastolic colour flow reversal extending into PA branches \\
\hline PA: pulmonary artery
\end{tabular}

\section{CONDUIT MORPHOLOGY}

Measurements of the conduit diameter at early to mid-systole were intended at the level of the conduit leaflets (valvular), 5-10 mm proximal to the leaflets (subvalvular), and $>10 \mathrm{~mm}$ distal to the leaflets (distal).

The conduit patency index (CPI) was calculated to assess narrowing or expansion of the conduit at the subvalvular and valvular levels from three months post implantation to a given follow-up time point $(=[$ conduit diameter at follow-up - conduit diameter at
3 months]/conduit diameter at 3 months\%). A negative CPI value suggests conduit narrowing due to, e.g., neointimal hyperplasia, and a positive CPI suggests conduit expansion.

The primary endpoint of the study was the XPV performance at postoperative 3, 6, 9, 12, 18 and 24 months. A favourable performance of the XPV was defined as freedom from all of the following: 1) a transvalvular peak systolic pressure gradient $>40 \mathrm{mmHg}$, 2) conduit narrowing as demonstrated by a reduction of the CPI of $20 \%$ or more, and 3) severe PR.

\section{STATISTICS}

Continuous variables with normal distribution were expressed as mean $\pm \mathrm{SD}$, while continuous variables with non-normal distribution were expressed as median and interquartile range (IQR). No formal statistics were performed in this study due to the small sample size and the exploratory nature of the study.

\section{Results}

As shown in Table 1, all echocardiographic parameters were measurable in the majority of cases (88-100\%), except for the distal conduit diameter, which could be reliably measured in only one third of cases. Therefore, measurements at the subvalvular and valvular conduit levels are reported in the results.

\section{STUDY PRIMARY ENDPOINT (Table 3)}

A favourable valve haemodynamic performance was achieved in all study animals. The average peak systolic pressure gradient (PG) at the valvular level was $25.6 \pm 9.7 \mathrm{mmHg}$ ( 3 months), $10.0 \pm 9.2 \mathrm{mmHg}$ (24 months) in the XPV group and was $18.4 \pm 6.6 \mathrm{mmHg}$ (3 months), $17.7 \pm 4.6 \mathrm{mmHg}$ (6 months) in the HPV group. Except for a single case that showed a temporary rise of peak $\mathrm{PG}>40 \mathrm{mmHg}$ at the three-month evaluation, all other cases did not show a significant rise $(>40 \mathrm{mmHg})$ at any time point and tended to decline over time (Figure 3 ). Therefore, although they tended to be higher early post procedure, peak PG values were eventually lower in the XPV group at the end of follow-up than in the HPV group at 3 and 6 months (Table 3).
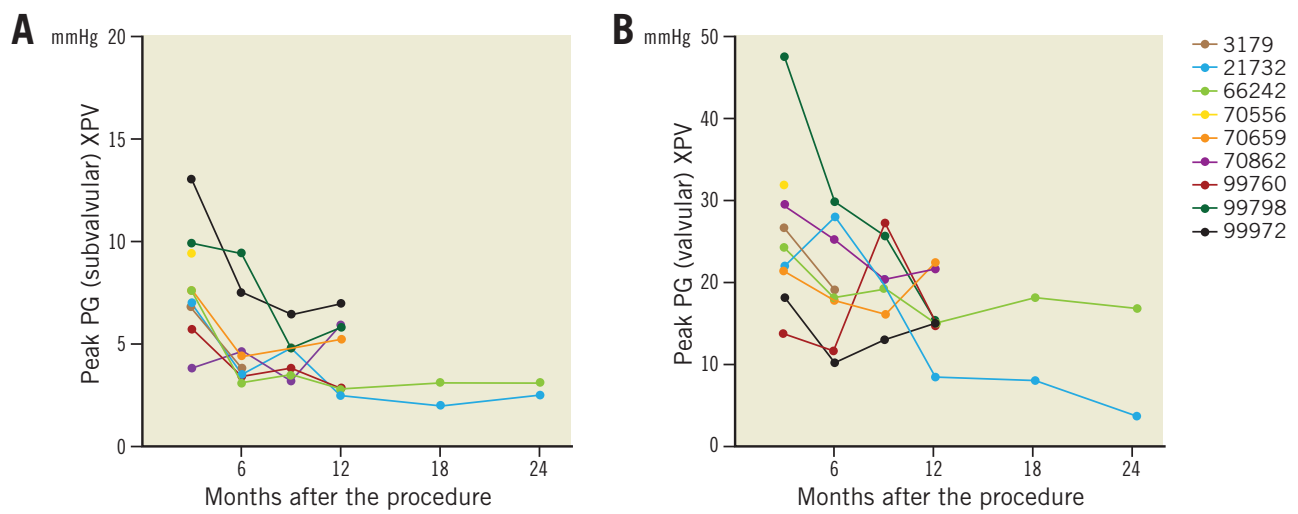

Figure 3. Serial changes of peak pressure gradient of individual animals at the subvalvular (A) and valvular (B) levels of the biodegradable pulmonary valved conduit. 
Table 3. Summary of quantitative echocardiographic assessments.

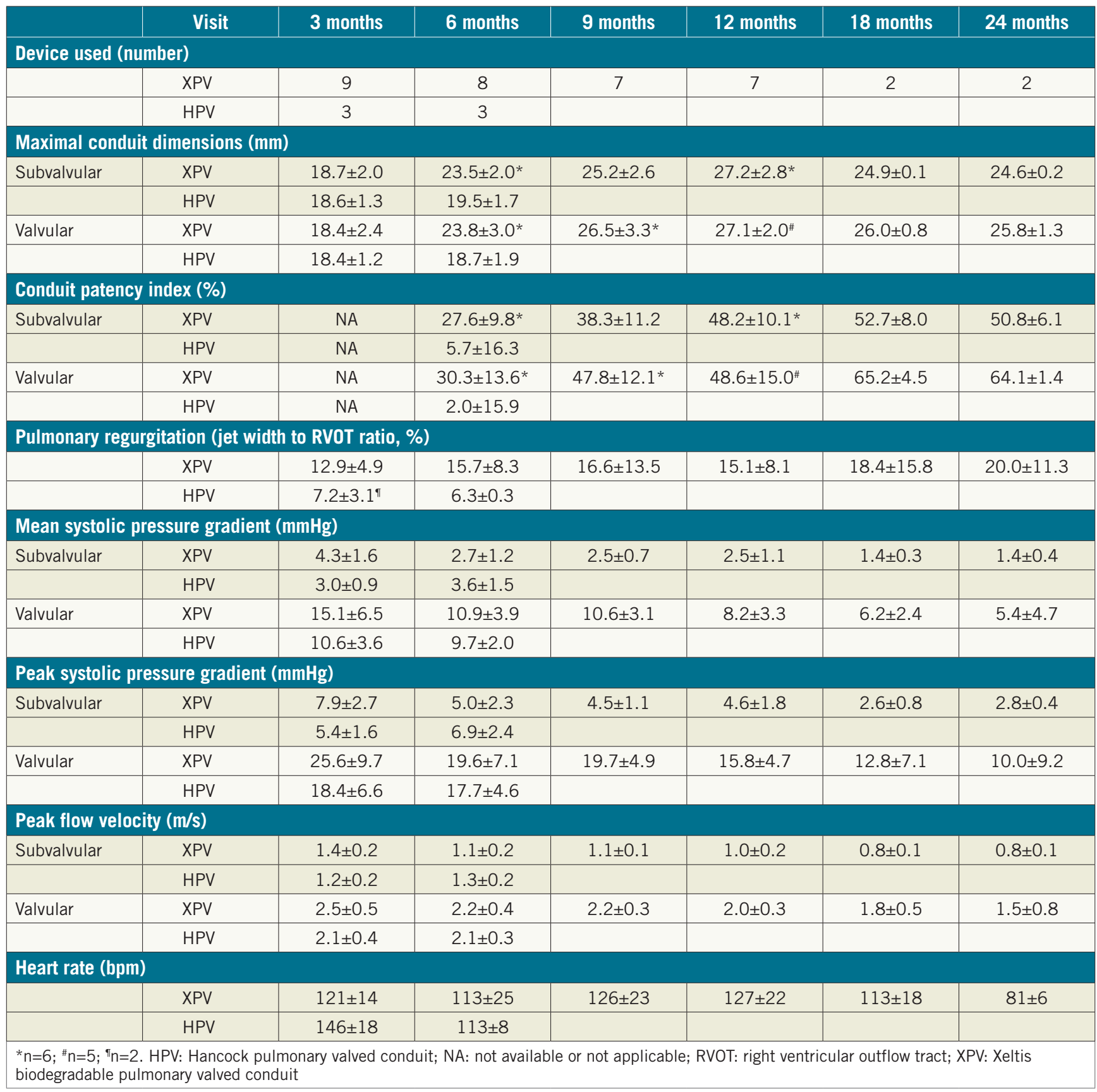

The CPI (\%) in the XPV group was $+27.6 \pm 9.8$ at six months and $+50.8 \pm 6.1$ at 24 months post procedure at the subvalvular level, while it was $+30.3 \pm 13.6$ at six months and $+64.1 \pm 1.4$ at 24 months at the valvular level. At six months, the CPI in the HPV group was $+2.0 \pm 15.9$ at valvular level and $+5.7 \pm 16.3$ at subvalvular level (Table 3). None of the animals in the XPV group had a narrowing $>20 \%$ across the conduit at any time point (Figure 4 ).

PR severity was trace or mild at all follow-up time points in eight animals and consistently moderate in one animal in the XPV group, while PR was trace in the HPV group animals up to six months (Table 4, Figure 5). In the XPV group, the PR jet width to
RVOT ratio was $<20 \%$ in five animals and $>20 \%$ in two animals 12 months after implantation. According to the flow reversal criteria, PR severity was trace or mild in six animals and moderate in one animal 12 months after procedure in the XPV group. There was a discrepancy of the PR severity between jet width criteria and flow reversal criteria in a single animal, in which PR was eventually adjudicated as mild.

\section{OTHER STUDY ENDPOINTS}

Other parameters of valve performance were examined in the XPV group at 12 and at 24 months after the procedure and compared to the 
A

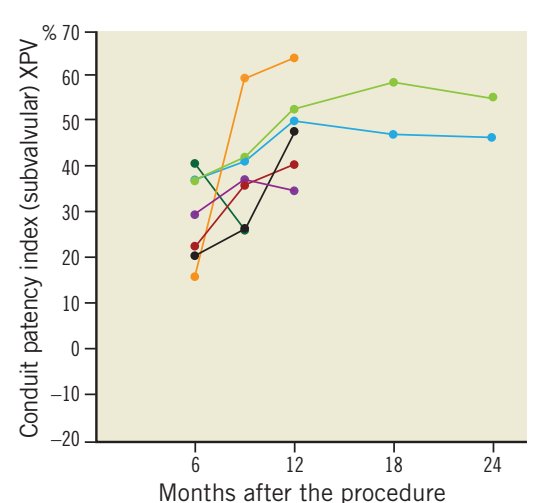

B

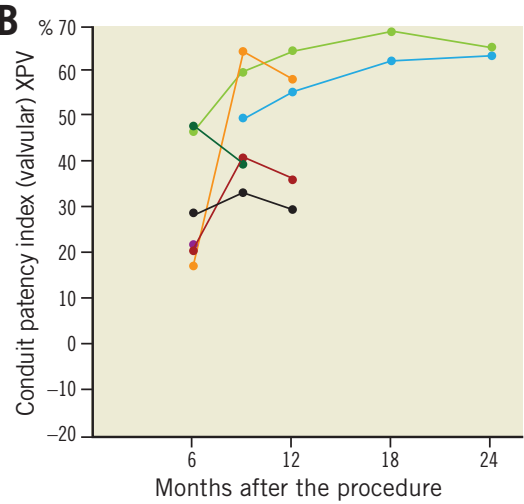

- 3179

- 21732

- 66242

$-70556$

- 70659

-70862
-09760

$-99760$

- 99798
- 99972

Figure 4. Serial changes of the conduit patency index of individual animals at the subvalvular (A) and valvular (B) levels of the Xeltis biodegradable pulmonary valved conduit.

Table 4. The severity of pulmonary regurgitation for sheep in the two study groups.

\begin{tabular}{|c|c|c|c|c|c|c|c|}
\hline Animal ID & Device & $\mathbf{3}$ months & $\mathbf{6}$ months & $\mathbf{9}$ months & $\mathbf{1 2}$ months & $\mathbf{1 8}$ months & $\mathbf{2 4}$ months \\
\hline 3179 & XPV & Mild & Mild & NA & NA & NA & Th \\
\hline 21732 & XPV & Mild & Trace & Trace & Trace & Trace \\
\hline 66242 & XPV & Moderate & Moderate & Moderate & Moderate & Moderate & Moderate \\
\hline 70556 & XPV & Mild & NA & NA & NA & NA & NA \\
\hline 70659 & XPV & Mild & Mild & Trace & Mild & NA \\
\hline 70862 & XPV & Mild & Mild & Mild & Mild & NA & NA \\
\hline 99760 & XPV & Trace & Mild & Mild & Mild & NA & NA \\
\hline 99798 & XPV & Mild & Mild & Mild & Mild & NA & NA \\
\hline 99972 & XPV & Mild & Mild & Trace & Trace & NA & NA \\
\hline 21079 & HPV & Mild & Mild & NA & NA & NA & NA \\
\hline 70215 & HPV & NA & Mild & NA & NA & NA \\
\hline 71256 & HPV & Mild & Mild & NA &
\end{tabular}
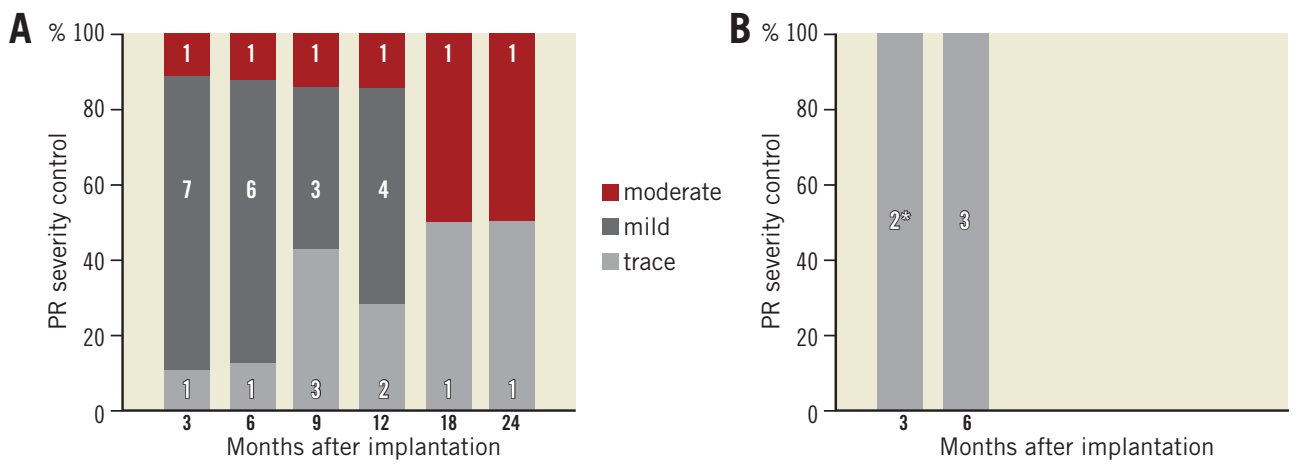

Figure 5. The severity of pulmonary regurgitation at different time points after implantation of the biodegradable pulmonary valved conduit (A) and the Hancock valved conduit (B). The number of subjects remaining at each time point, for each severity, is shown in the bars. *Animal \#70215 images were non-analysable.

respective measurements performed at 3 and 6 months in the HPV group. Mean systolic PG at the valvular level was $15.1 \pm 6.5 \mathrm{mmHg}$ ( 3 months), $10.9 \pm 3.9$ (6 months) and $5.4 \pm 4.7 \mathrm{mmHg}$ (24 months) in the XPV group and was $10.6 \pm 3.6 \mathrm{mmHg}$ (3 months) and $9.7 \pm 2.0 \mathrm{mmHg}$ (6 months) in the HPV group. Mean systolic PG was $<20 \mathrm{mmHg}$ in all XPV group animals at both the subvalvular and the valvular levels of the conduit 12 months $(n=7)$ and 24 months $(n=2)$ after the procedure. Mean systolic PG decreased over time in the XPV group while it did not change in the HPV group between 3 and 6 months after implantation (Figure 6).

None of the animals in the XPV group had a peak velocity $>3 \mathrm{~m} / \mathrm{s}$ at subvalvular or valvular levels of the conduit 12 and 
A

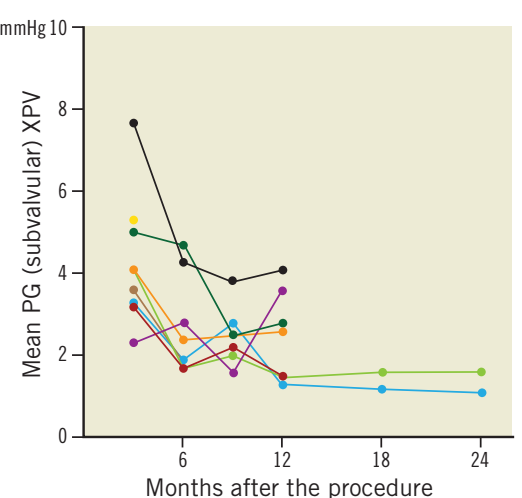

B

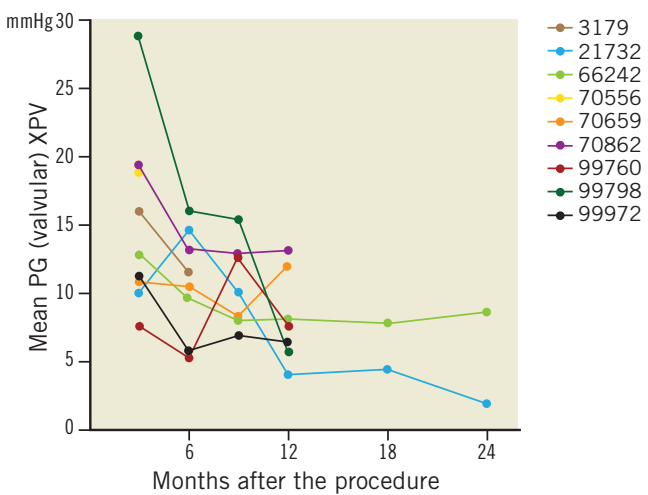

Figure 6. Serial changes of mean pressure gradient of individual animals at the subvalvular (A) and valvular (B) levels of the biodegradable pulmonary valved conduit.

24 months after the procedure $(n=7)$. Although one animal had a peak velocity $>3 \mathrm{~m} / \mathrm{s}$ at the valvular level 3 months after the procedure, the peak velocity at 6 months decreased to $<3 \mathrm{~m} / \mathrm{s}$. Peak velocity decreased over time in the XPV group (Figure 7, Table 3), while peak velocity in the HPV group did not change between 3 and 6 months (Table 3).

The subvalvular conduit diameter of XPV increased from $18.7 \pm 2.0$ at 3 months to $27.2 \pm 2.8$ and $24.6 \pm 0.2$ at 12 and 24 months, respectively. In contrast, the subvalvular conduit diameter in the HPV group was $18.6 \pm 1.3$ and $19.5 \pm 1.7$ at 3 and 6 months, respectively. Similarly, the valvular conduit diameter of XPV increased from $18.4 \pm 2.4$ at 3 months to $27.1 \pm 2.0$ and $25.8 \pm 1.3$ at 12 and 24 months, respectively, while in the HPV group it was $18.4 \pm 1.2$ vs. $18.7 \pm 1.9$ at 3 and 6 months, respectively (Figure 8, Table 3).

\section{Discussion}

In $20-40 \%$ of adults with congenital heart disease, there is an RVOT abnormality requiring implantation of an artificial conduit between the RV and the $\mathrm{PA}^{1,2}$. Regardless of the technique used to reconstruct the RVOT, conduit dysfunction is common, and freedom from degeneration at 10 years is $51 \%$ in the case of homografts implanted before the age of 10 years ${ }^{5}$. Accordingly, many patients have their third RVOT intervention by the age of 20 years $^{21}$. Reintervention is associated with discomfort, disfigurement, cost, morbidity, and mortality.

The XPV is a next-generation conduit fabricated from a novel supramolecular elastomer that enables endogenous cells to populate the scaffold and to produce matrix. In the present study, echocardiographic analysis by an independent core laboratory showed a favourable haemodynamic performance as well as an acceptable regurgitation severity of the XPV, sustained up to two years after implantation. Morphologically, the XPV showed no narrowing or abnormal growth during the follow-up period. The definition of a favourable valve haemodynamic performance in this report was based on the best clinical judgement, published data on established pulmonary prosthetic valves/conduits, and practice guidelines ${ }^{19,22,23}$.

In two animals, haemodynamic findings warrant more discussion. Animal \#99798 initially had a high peak systolic PG at the valvular level at three months, which was consistently improving on later echocardiograms, eventually approaching acceptable values. The peak transvalvular gradient decreased to $<30 \mathrm{mmHg}$ at six months and to $<20 \mathrm{mmHg}$ on the 12 -month echocardiogram.

\section{A}

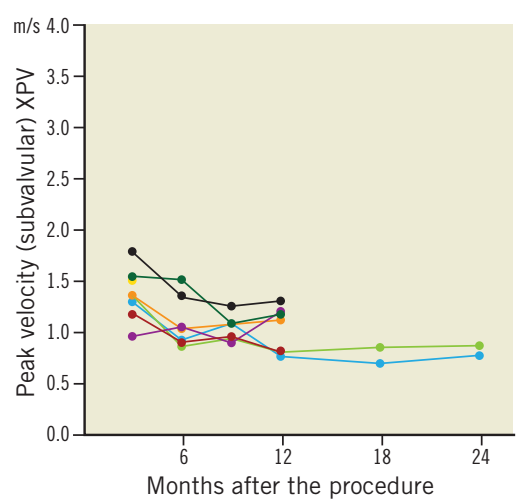

B

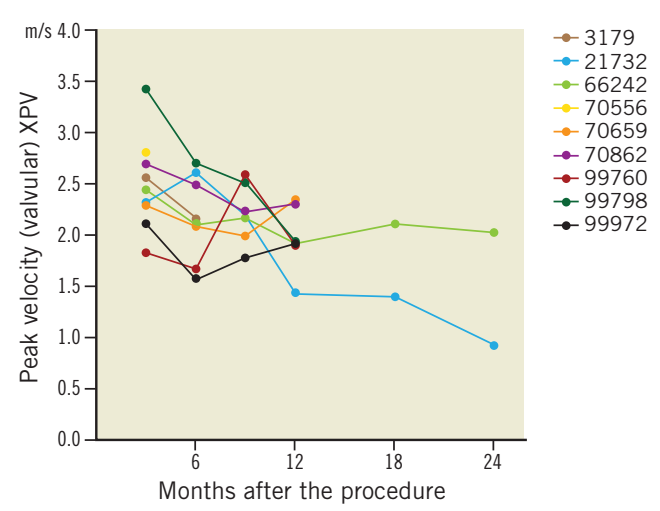

Figure 7. Serial changes of peak velocity of individual animals at the subvalvular (A) and valvular (B) levels of the biodegradable pulmonary valved conduit. 

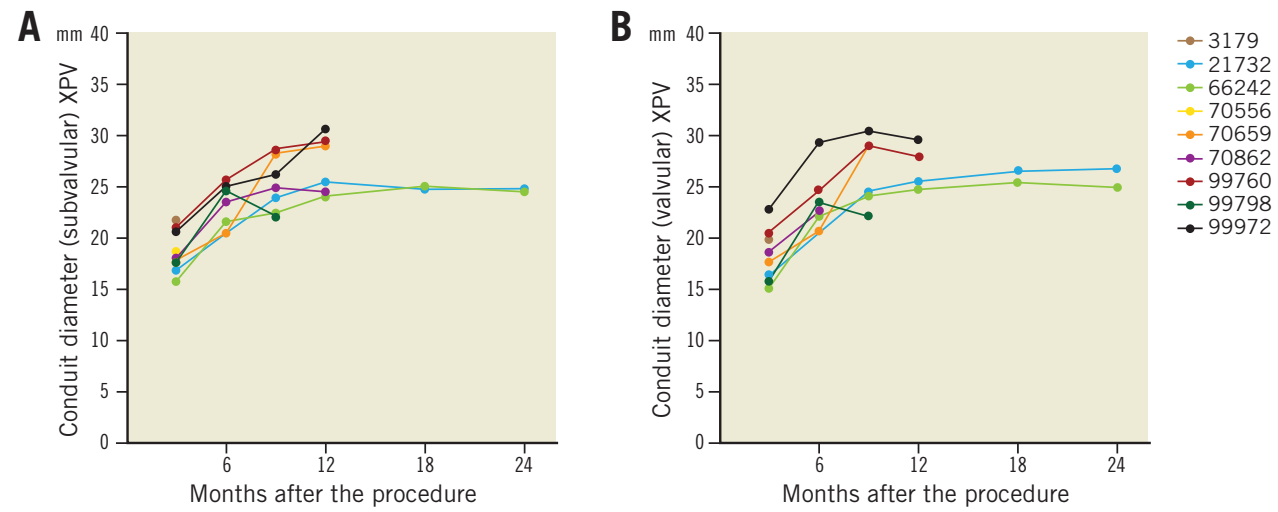

Figure 8. Serial changes of conduit diameter of individual animals at the subvalvular (A) and valvular (B) levels of the biodegradable pulmonary valved conduit.

There are no clear echocardiographic findings, or other clinical ones, to explain this temporarily high PG. However, a transient thrombus is a likely explanation.

Moderate PR was consistently seen in animal \#66242 up to 24 months after the procedure. This animal showed a CPI of up to $+70 \%$, denoting a considerable increase in the conduit diameter during follow-up, ranking highest among all the animals in terms of luminal expansion. On the other hand, the actual diameter of the XPV in that animal (\#66242) was $25 \mathrm{~mm}$, which is the same diameter as another animal (\#21732) at the latest follow-up at 24 months. These values are, in fact, only $4 \mathrm{~mm}$ larger than the nominal implantation diameter of $21 \mathrm{~mm}$. Likewise, another animal (\#99972) with even more increased diameter at 12-month follow-up had only trace PR.

There are limited data on precise echo Doppler cut-off values to define prosthetic pulmonary valve dysfunction. The American Society of Echocardiography guidelines recommend using RV-to-PA peak velocity as well as peak and mean PG for the evaluation of prosthetic pulmonary valve function. The normal performance of a pulmonary prosthetic valve is defined by a peak transprosthetic velocity of $<3.2 \mathrm{~m} / \mathrm{s}$ and a mean transprosthetic pressure gradient $<20 \mathrm{mmHg}^{18}$. In the Melody Transcatheter Pulmonary Valve Post-Approval Study (NCT01186692), a mean pressure gradient of $\leq 30 \mathrm{mmHg}$ and $\mathrm{PR}<$ moderate at six months were used as the intended transcatheter valve performance criteria ${ }^{24}$. Procedural success was defined as a transcatheter pulmonary valve implanted in the desired location, and RV-PA peak gradient $<35 \mathrm{mmHg}$ (derived from invasive measurement), no more than mild PR on angiography, and freedom from explantation at 24 hours post implantation ${ }^{24}$. Structural valve deterioration of the surgically implanted Freestyle ${ }^{\mathrm{TM}}$ bioprosthetic valve (Medtronic) was defined as a composite of significant stenosis (a peak transvalvular gradient of $>50 \mathrm{mmHg}$ or a mean transvalvular gradient of $>35 \mathrm{mmHg}$ ), or significant regurgitation (moderate or greater) on echocardiography ${ }^{25}$.

In line with the haemodynamic data of established transcatheter and surgical pulmonary valve prostheses as well as the Hancock $22 \mathrm{~mm}$ conduit used in this study, the XPV has favourable haemodynamic data. These data are to be confirmed in a human clinical study, which is currently underway.

\section{Limitations}

Interpretation of this study is limited by the relatively small number of echocardiographic evaluations available. Echocardiograms at the immediate postoperative time point $(\mathrm{t}=0)$ were not available. Absence of a clear electrocardiographic signal on echocardiographic images was another limitation, particularly for PR assessment. Ideally, the conduit dimensions should be quantified on a three-dimensional imaging modality.

\section{Conclusions}

The XPV shows encouraging results in an adult sheep model up to 24 months after implantation without luminal narrowing or haemodynamic deterioration.

\section{Impact on daily practice}

The use of biodegradable valves and conduits, such as the Xeltis pulmonary valved conduit endogenous tissue restorative technology would minimise or even eliminate the complications related to the use of prosthetic materials. Patients would have fewer thrombotic or degenerative prosthetic valves, thus less need for antithrombotic use as well as less need for reintervention. Another important aspect of this novel endogenous restorative technology is that it allows growth of the implanted material. The latter is essential in treating children with congenital heart disease. This study suggests that haemodynamic performance of a novel pulmonary valved conduit is favourable up to two years after implantation in a preclinical setting.

\section{Guest Editor}

This paper was guest edited by Alec Vahanian, $\mathrm{MD}, \mathrm{PhD}$; Department of Cardiology, Hôpital Bichat, Paris, and University Paris VII, Paris, France. 


\section{Conflict of interest statement}

M. Brugmans and M. Cox are employed by Xeltis. P.W.Serruys is part of the Scientific Advisory Board of Xeltis. The other authors have no conflicts of interest to declare. The Guest Editor is a consultant for Edwards Lifesciences.

\section{References}

1. Warnes CA, Williams RG, Bashore TM, Child JS, Connolly HM, Dearani JA, del Nido P, Fasules JW, Graham TP Jr, Hijazi ZM, Hunt SA, King ME, Landzberg MJ, Miner PD, Radford MJ, Walsh EP, Webb GD, Smith SC Jr, Jacobs AK, Adams CD, Anderson JL, Antman EM, Buller CE, Creager MA, Ettinger SM, Halperin JL, Hunt SA, Krumholz HM, Kushner FG, Lytle BW, Nishimura RA, Page RL, Riegel B, Tarkington LG, Yancy CW; American College of Cardiology; American Heart Association Task Force on Practice Guidelines (Writing Committee to Develop Guidelines on the Management of Adults With Congenital Heart Disease); American Society of Echocardiography; Heart Rhythm Society; International Society for Adult Congenital Heart Disease; Society for Cardiovascular Angiography and Interventions; Society of Thoracic Surgeons. ACC/ AHA 2008 guidelines for the management of adults with congenital heart disease: a report of the American College of Cardiology/ American Heart Association Task Force on Practice Guidelines (Writing Committee to Develop Guidelines on the Management of Adults With Congenital Heart Disease). Developed in Collaboration With the American Society of Echocardiography, Heart Rhythm Society, International Society for Adult Congenital Heart Disease, Society for Cardiovascular Angiography and Interventions, and Society of Thoracic Surgeons. J Am Coll Cardiol. 2008;52:e143-263.

2. Kaltman JR, Andropoulos DB, Checchia PA, Gaynor JW, Hoffman TM, Laussen PC, Ohye RG, Pearson GD, Pigula F, Tweddell J, Wernovsky G, Del Nido P; Perioperative Working Group. Report of the pediatric heart network and national heart, lung, and blood institute working group on the perioperative management of congenital heart disease. Circulation. 2010;121:2766-72.

3. Lee C, Park CS, Lee CH, Kwak JG, Kim SJ, Shim WS, Song JY, Choi EY, Lee SY. Durability of bioprosthetic valves in the pulmonary position: long-term follow-up of 181 implants in patients with congenital heart disease. $J$ Thorac Cardiovasc Surg. 2011;142:351-8.

4. de Ruijter FT, Weenink I, Hitchcock FJ, Meijboom EJ, Bennink GB. Right ventricular dysfunction and pulmonary valve replacement after correction of tetralogy of Fallot. Ann Thorac Surg. 2002;73:1794-800.

5. Boethig D, Goerler H, Westhoff-Bleck M, Ono M, Daiber A, Haverich A, Breymann T. Evaluation of 188 consecutive homografts implanted in pulmonary position after 20 years. Eur $J$ Cardiothorac Surg. 2007;32:133-42.

6. Hallbergson A, Gauvreau K, Powell AJ, Geva T. Right ventricular remodeling after pulmonary valve replacement: early gains, late losses. Ann Thorac Surg. 2015;99:660-6.
7. Cebotari S, Lichtenberg A, Tudorache I, Hilfiker A, Mertsching H, Leyh R, Breymann T, Kallenbach K, Maniuc L, Batrinac A, Repin O, Maliga O, Ciubotaru A, Haverich A. Clinical application of tissue engineered human heart valves using autologous progenitor cells. Circulation. 2006;114:I132-7.

8. Rieder E, Seebacher G, Kasimir MT, Eichmair E, Winter B, Dekan B, Wolner E, Simon P, Weigel G. Tissue engineering of heart valves: decellularized porcine and human valve scaffolds differ importantly in residual potential to attract monocytic cells. Circulation. 2005;111:2792-7.

9. Sutherland FW, Perry TE, Yu Y, Sherwood MC, Rabkin E, Masuda Y, Garcia GA, McLellan DL, Engelmayr GC Jr, Sacks MS, Schoen FJ, Mayer JE Jr. From stem cells to viable autologous semilunar heart valve. Circulation. 2005;111:2783-91.

10. Lichtenberg A, Tudorache I, Cebotari S, Suprunov M, Tudorache G, Goerler H, Park JK, Hilfiker-Kleiner D, RingesLichtenberg S, Karck M, Brandes G, Hilfiker A, Haverich A. Preclinical testing of tissue-engineered heart valves re-endothelialized under simulated physiological conditions. Circulation. 2006; 114:I559-65.

11. Hoerstrup SP, Sodian R, Daebritz S, Wang J, Bacha EA, Martin DP, Moran AM, Guleserian KJ, Sperling JS, Kaushal S, Vacanti JP, Schoen FJ, Mayer JE Jr. Functional living trileaflet heart valves grown in vitro. Circulation. 2000;102:III44-9.

12. Mol A, Rutten MC, Driessen NJ, Bouten CV, Zund G, Baaijens FP, Hoerstrup SP. Autologous human tissue-engineered heart valves: prospects for systemic application. Circulation. 2006;114:I152-8

13. Talacua H, Smits AI, Muylaert DE, van Rijswijk JW, Vink A, Verhaar MC, Driessen-Mol A, van Herwerden LA, Bouten CV, Kluin J, Baaijens FP. In Situ Tissue Engineering of Functional Small-Diameter Blood Vessels by Host Circulating Cells Only. Tissue Eng Part A. 2015;21:2583-94.

14. Bockeria LA, Svanidze O, Kim A, Shatalov K, Makarenko V, Cox M, Carrel T. Total cavopulmonary connection with a new bioabsorbable vascular graft: First clinical experience. J Thorac Cardiovasc Surg. 2017;153:1542-50.

15. Kappetein AP, Head SJ, Généreux P, Piazza N, van Mieghem NM, Blackstone EH, Brott TG, Cohen DJ, Cutlip DE, van Es GA, Hahn RT, Kirtane AJ, Krucoff MW, Kodali S, Mack MJ, Mehran R, Rodés-Cabau J, Vranckx P, Webb JG, Windecker S, Serruys PW, Leon MB. Updated standardized endpoint definitions for transcatheter aortic valve implantation: the Valve Academic Research Consortium-2 consensus document. Eur Heart J. 2012;33:2403-18.

16. Baumgartner $\mathrm{H}$, Hung J, Bermejo J, Chambers JB, Evangelista A, Griffin BP, Iung B, Otto CM, Pellikka PA, Quinones M; American Society of Echocardiography; European Association of Echocardiography. Echocardiographic assessment of valve stenosis: EAE/ASE recommendations for clinical practice. J Am Soc Echocardiogr. 2009;22:1-23.

17. Lancellotti P, Tribouilloy C, Hagendorff A, Moura L, Popescu BA, Agricola E, Monin JL, Pierard LA, Badano L, 
Zamorano JL; European Association of Echocardiography. European Association of Echocardiography recommendations for the assessment of valvular regurgitation. Part 1: aortic and pulmonary regurgitation (native valve disease). Eur $J$ Echocardiogr. 2010;11:223-44.

18. Zoghbi WA, Chambers JB, Dumesnil JG, Foster E, Gottdiener JS, Grayburn PA, Khandheria BK, Levine RA, Marx GR, Miller FA Jr, Nakatani S, Quinones MA, Rakowski H, Rodriguez LL, Swaminathan M, Waggoner AD, Weissman NJ, Zabalgoitia M; American Society of Echocardiography's Guidelines and Standards Committee; Task Force on Prosthetic Valves; American College of Cardiology Cardiovascular Imaging Committee; Cardiac Imaging Committee of the American Heart Association; European Association of Echocardiography; European Society of Cardiology; Japanese Society of Echocardiography; Canadian Society of Echocardiography; American College of Cardiology Foundation; American Heart Association; European Association of Echocardiography; European Society of Cardiology; Japanese Society of Echocardiography; Canadian Society of Echocardiography. Recommendations for evaluation of prosthetic valves with echocardiography and doppler ultrasound: a report From the American Society of Echocardiography's Guidelines and Standards Committee and the Task Force on Prosthetic Valves, developed in conjunction with the American College of Cardiology Cardiovascular Imaging Committee, Cardiac Imaging Committee of the American Heart Association, the European Association of Echocardiography, a registered branch of the European Society of Cardiology, the Japanese Society of Echocardiography and the Canadian Society of Echocardiography, endorsed by the American College of Cardiology Foundation, American Heart Association, European Association of Echocardiography, a registered branch of the European Society of Cardiology, the Japanese Society of Echocardiography, and Canadian Society of Echocardiography. J Am Soc Echocardiogr. 2009;22:975-1014.

19. Rudski LG, Lai WW, Afilalo J, Hua L, Handschumacher MD, Chandrasekaran K, Solomon SD, Louie EK, Schiller NB. Guidelines for the echocardiographic assessment of the right heart in adults: a report from the American Society of Echocardiography endorsed by the European Association of Echocardiography, a registered branch of the European Society of Cardiology, and the Canadian Society of Echocardiography. J Am Soc Echocardiogr. 2010;23:685-713.

20. Brown DW, McElhinney DB, Araoz PA, Zahn EM, Vincent JA, Cheatham JP, Jones TK, Hellenbrand WE, O'Leary PW. Reliability and accuracy of echocardiographic right heart evaluation in the U.S. Melody Valve Investigational Trial. J Am Soc Echocardiogr. 2012;25:383-92.e4.

21. Malekzadeh-Milani S, Ladouceur M, Iserin L, Bonnet D, Boudjemline Y. Incidence and outcomes of right-sided endocarditis in patients with congenital heart disease after surgical or transcatheter pulmonary valve implantation. J Thorac Cardiovasc Surg. 2014;148:2253-9.

22. Zoghbi WA, Adams D, Bonow RO, Enriquez-Sarano M, Foster E, Grayburn PA, Hahn RT, Han Y, Hung J, Lang RM, Little SH, Shah DJ, Shernan S, Thavendiranathan P, Thomas JD, Weissman NJ. Recommendations for Noninvasive Evaluation of Native Valvular Regurgitation: A Report from the American Society of Echocardiography Developed in Collaboration with the Society for Cardiovascular Magnetic Resonance. J Am Soc Echocardiogr. 2017;30:303-71.

23. Quinones MA, Otto CM, Stoddard M, Waggoner A, Zoghbi WA; Doppler Quantification Task Force of the Nomenclature and Standards Committee of the American Society of Echocardiography. Recommendations for quantification of Doppler echocardiography: a report from the Doppler Quantification Task Force of the Nomenclature and Standards Committee of the American Society of Echocardiography. J Am Soc Echocardiogr. 2002;15:167-84.

24. Armstrong AK, Balzer DT, Cabalka AK, Gray RG, Javois AJ, Moore JW, Rome JJ, Turner DR, Zellers TM, Kreutzer J. One-year follow-up of the Melody transcatheter pulmonary valve multicenter post-approval study. JACC Cardiovasc Interv. 2014;7:1254-62.

25. Dunne B, Suthers E, Xiao P, Xiao J, Litton E, Andrews D. Medium-term outcomes after pulmonary valve replacement with the Freestyle valve for congenital heart disease: a case series. Eur $J$ Cardiothorac Surg. 2016;49:e105-11. 